NASA/TM-2003-212485

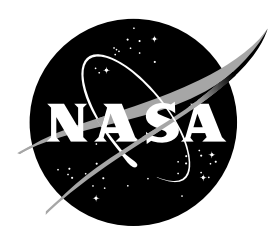

\title{
Coupling of 3,8-Dibromo-1,10-Phenanthroline With 3,5-Diethynylheptyloxybenzene: A Suzuki/Miyaura Versus a Sonogashira Perspective
}

Jinhua Yang, Woon Su Oh, and Ian A. Elder

University of Missouri at Rolla, Rolla, Missouri

Nicholas Leventis

Glenn Research Center, Cleveland, Ohio

Chariklia Sotiriou-Leventis

University of Missouri at Rolla, Rolla, Missouri 
Since its founding, NASA has been dedicated to the advancement of aeronautics and space science. The NASA Scientific and Technical Information (STI) Program Office plays a key part in helping NASA maintain this important role.

The NASA STI Program Office is operated by Langley Research Center, the Lead Center for NASA's scientific and technical information. The NASA STI Program Office provides access to the NASA STI Database, the largest collection of aeronautical and space science STI in the world. The Program Office is also NASA's institutional mechanism for disseminating the results of its research and development activities. These results are published by NASA in the NASA STI Report Series, which includes the following report types:

- $\quad$ TECHNICAL PUBLICATION. Reports of completed research or a major significant phase of research that present the results of NASA programs and include extensive data or theoretical analysis. Includes compilations of significant scientific and technical data and information deemed to be of continuing reference value. NASA's counterpart of peerreviewed formal professional papers but has less stringent limitations on manuscript length and extent of graphic presentations.

- TECHNICAL MEMORANDUM. Scientific and technical findings that are preliminary or of specialized interest, e.g., quick release reports, working papers, and bibliographies that contain minimal annotation. Does not contain extensive analysis.

- CONTRACTOR REPORT. Scientific and technical findings by NASA-sponsored contractors and grantees.
- CONFERENCE PUBLICATION. Collected papers from scientific and technical conferences, symposia, seminars, or other meetings sponsored or cosponsored by NASA.

- SPECIAL PUBLICATION. Scientific, technical, or historical information from NASA programs, projects, and missions, often concerned with subjects having substantial public interest.

- TECHNICAL TRANSLATION. Englishlanguage translations of foreign scientific and technical material pertinent to NASA's mission.

Specialized services that complement the STI Program Office's diverse offerings include creating custom thesauri, building customized databases, organizing and publishing research results ... even providing videos.

For more information about the NASA STI Program Office, see the following:

- Access the NASA STI Program Home Page at http://www.sti.nasa.gov

- E-mail your question via the Internet to help@sti.nasa.gov

- Fax your question to the NASA Access Help Desk at 301-621-0134

- Telephone the NASA Access Help Desk at 301-621-0390

- Write to:

NASA Access Help Desk

NASA Center for AeroSpace Information 7121 Standard Drive

Hanover, MD 21076 
NASA/TM-2003-212485

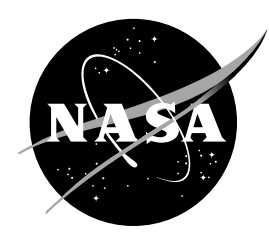

\section{Coupling of 3,8-Dibromo-1,10-Phenanthroline With 3,5-Diethynylheptyloxybenzene: A Suzuki/Miyaura Versus a Sonogashira Perspective}

Jinhua Yang, Woon Su Oh, and Ian A. Elder

University of Missouri at Rolla, Rolla, Missouri

Nicholas Leventis

Glenn Research Center, Cleveland, Ohio

Chariklia Sotiriou-Leventis

University of Missouri at Rolla, Rolla, Missouri

National Aeronautics and

Space Administration

Glenn Research Center 


\section{Acknowledgments}

We gratefully acknowledge support by the Petroleum Research Fund, administered by the ACS (Grant No. 35154-ACS), and from the National Cancer Institute (Grant No. 1 R15 CA82141-01A2 to Chariklia Sotiriou-Leventis). We also thank Dr. Nathan D. Leigh at the University of Missouri, Columbia for obtaining the MS spectra.

The Propulsion and Power Program at NASA Glenn Research Center sponsored this work.

Available from

NASA Center for Aerospace Information 7121 Standard Drive

Hanover, MD 21076
National Technical Information Service 5285 Port Royal Road Springfield, VA 22100

Available electronically at http:/ /gltrs.grc.nasa.gov 


\title{
COUPLING OF 3,8-DIBROMO-1,10-PHENANTHROLINE WITH 3,5-DIETHYNYLHEPTYLOXYBENZENE: A SUZUKI/MIYAURA VERSUS A SONOGASHIRA PERSPECTIVE
}

\author{
Jinhua Yang, Woon Su Oh, Ian A. Elder \\ University of Missouri-Rolla \\ Department of Chemistry \\ Rolla, Missouri 65409
}

Nicholas Leventis

National Aeronautics and Space Administration

Glenn Research Center

Cleveland, Ohio 44135

Chariklia Sotiriou-Leventis

University of Missouri-Rolla

Department of Chemistry

Rolla, Missouri 65409

\begin{abstract}
We report a new application of the Suzuki-Miyaura reaction whereas two bifunctional reactants, 3,8-dibromo-1,10-phenanthroline and 3,5-diethynylheptyloxylbenzene (9), yield 3,8-bis (3-ethynyl-5-heptyloxyphenylethynyl)-1,10-phenanthroline (2) efficiently (74\% yield) without polymerization. This was achieved by reacting a stoichiometric amount of 9 and $\left(\mathrm{Me}_{3} \mathrm{Si}\right)_{2} \mathrm{NLi}$ to obtain quantitatively the monoacetylide anion of 9 (10). The latter was activated with B-methoxy-9-BBN and reacted in analogy to the alkynyl copper complex of a Sonogashira route. However, in the Sonogashira reaction, the alkynyl copper complex is present in small equilibrium concentrations and polymerization takes place even when reagents are mixed slowly. Actually the Sonogashira route gave no desired product 2 , as the latter polymerizes easily via homo-coupling in the presence of air and $\mathrm{Cu}(\mathrm{I})$.

Sonogashira coupling involves the palladium(0) catalyzed reaction of terminal alkynes with vinyl or aryl halides in the presence of $\mathrm{CuI}$ or $\mathrm{CuBr}$ and an amine such as triethyl or diisopropyl amine. ${ }^{1}$ Mechanistically, oxidative addition of the organic halide gives a $\mathrm{Pd}(\mathrm{II})$ intermediate, which undergoes transmetallation with the alkynyl copper (generated in small equilibrium quantities from the terminal alkyne, base, and copper iodide). Reductive elimination with coupling of the two organic ligands gives the product and regenerates the $\operatorname{Pd}(0)$ catalyst. For convenience, oftentimes the palladium catalyst is introduced as a stable, soluble $\mathrm{Pd}(\mathrm{II})$ derivative such as $\mathrm{Pd}\left(\mathrm{PPh}_{3}\right)_{2} \mathrm{Cl}_{2}$. This complex is rapidly reduced by the terminal alkyne in situ to give the catalytic $\operatorname{Pd}(0)$ species. Due to the mild conditions usually employed (e.g. reaction at room temperature) and the use of inexpensive reagents, the Sonogashira coupling reaction has been a very convenient synthetic method for the preparation of aromatic alkynes.

Despite its convenience, the Sonogashira reaction cannot be used for coupling of dialkynes with dibromoaromatic compounds. First, bifunctionality on both reactants generally leads to
\end{abstract}


polymerization. Furthermore, even though it might be considered that slow syringe-pump addition of the dialkyne might lead to the desirable product, unfortunately during work-up, the bisacetylenic product itself tends to undergo oxidative coupling in the presence of air and $\mathrm{Cu}(\mathrm{I})$, known as homocoupling, ${ }^{2}$ leading again to polymerization.

In brief, the main causes of polymerization during the Sonogashira coupling reaction are: (a) the generation of only a small equilibrium amount of the alkynyl anion, and (b) the presence of catalytic amounts of copper (related to homocoupling). It seems that if the alkynyl anion could be generated quantitatively and activated by means other than copper, polymerization would be avoided.

An alternative procedure that also leads to aryl alkynes is the Suzuki/Miyaura coupling reaction. ${ }^{3}$ According to that procedure, the alkynyl anion is formed quantitatively by the reaction of a terminal alkyne with a stoichiometric amount of a strong base (e.g., $\left.\left(\mathrm{Me}_{3} \mathrm{Si}\right)_{2} \mathrm{NLi}\right)$. Subsequently, the alkynyl anion is activated via reaction with B-methoxy-9-borabicyclo[3.3.1]nonane (B-methoxy-9-BBN) to form a stable methoxy(alkynyl)borate complex, which subsequently reacts with an aryl bromide in the presence of $\operatorname{Pd}(0)$ to yield identical products with the corresponding Sonogashira coupling reaction that involves the same alkyne and aryl bromide starting materials. The Suzuki/Miyaura route uses harsher conditions (strong base) and a more expensive reagent (B-methoxy-9-BBN). However, it involves quantitative formation of the alkynyl anion and it does not use copper salts, so polymerization with bifunctional terminal halide and dibromoaromatic compounds should not be an issue.

These inferences were confirmed by comparing the synthesis of 3,8-bis(4-isonicotynoylphenylethynyl)-1,10-phenanthroline (1) with the synthesis of 3,8-bis(3-ethynyl-5-heptyloxyphenylethynyl)-1,10-phenanthroline (2). Compound 1 was designed as a ligand for intramolecular electron transfer quenching, while metal complexes of compound 2 were designed as building blocks of larger conjugated systems.

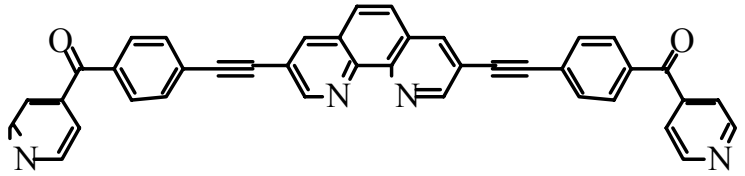

1

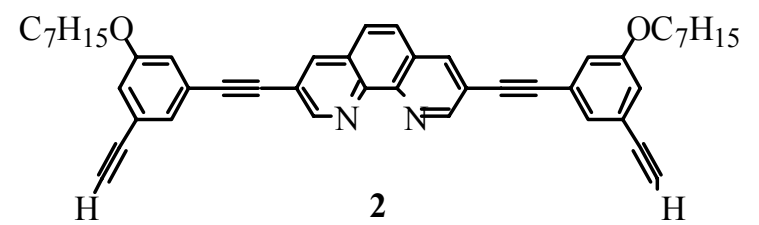

2
$\mathrm{H}$

Sonogashira coupling of 4-(p-bromobenzoyl)pyridine (3) with 3,8-bisethynyl-1,10-phenanthroline (4, prepared also via Sonogashira coupling of TMS-protected acetylene and 3,8-dibromo-1,10-phenanthroline) proceeds uneventfully giving 1 in $32 \%$ yield (Scheme 1). ${ }^{4}$ On the other hand, direct Sonogashira coupling of 3,8-dibromo-1,10-phenanthroline with 3,5-diethynylheptyloxybenzene (9) under the same conditions led to an intractable polymer. 


\section{Scheme 1}

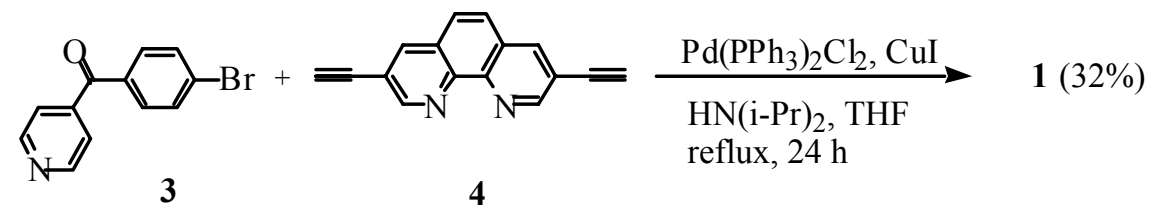

Compound 9 was synthesized according to Scheme 2. Pentabromophenol (5) was dehalogenated in benzene by $\mathrm{AlCl}_{3}$ to give 3,5-dibromophenol (6), ${ }^{6}$ which then reacted with 1-bromoheptane to yield 3,5-dibromoheptyloxylbenzene (7). A direct Sonogashira coupling of 7 with trimethylsilylacetylene catalyzed by $\mathrm{Pd}(\mathrm{PhCN})_{2} \mathrm{Cl}_{2}$ with $\mathrm{P}(t-\mathrm{Bu})_{3}$ in the presence of $\mathrm{CuI}$ and diisopropylamine at room temperature gave compound 8 , which was subsequently deprotected in the presence of $\mathrm{NaOH}$ in $\mathrm{CH}_{2} \mathrm{Cl}_{2} / \mathrm{MeOH}$ to give compound 9 in $65 \%$ overall yield from 5 .

\section{Scheme 2}
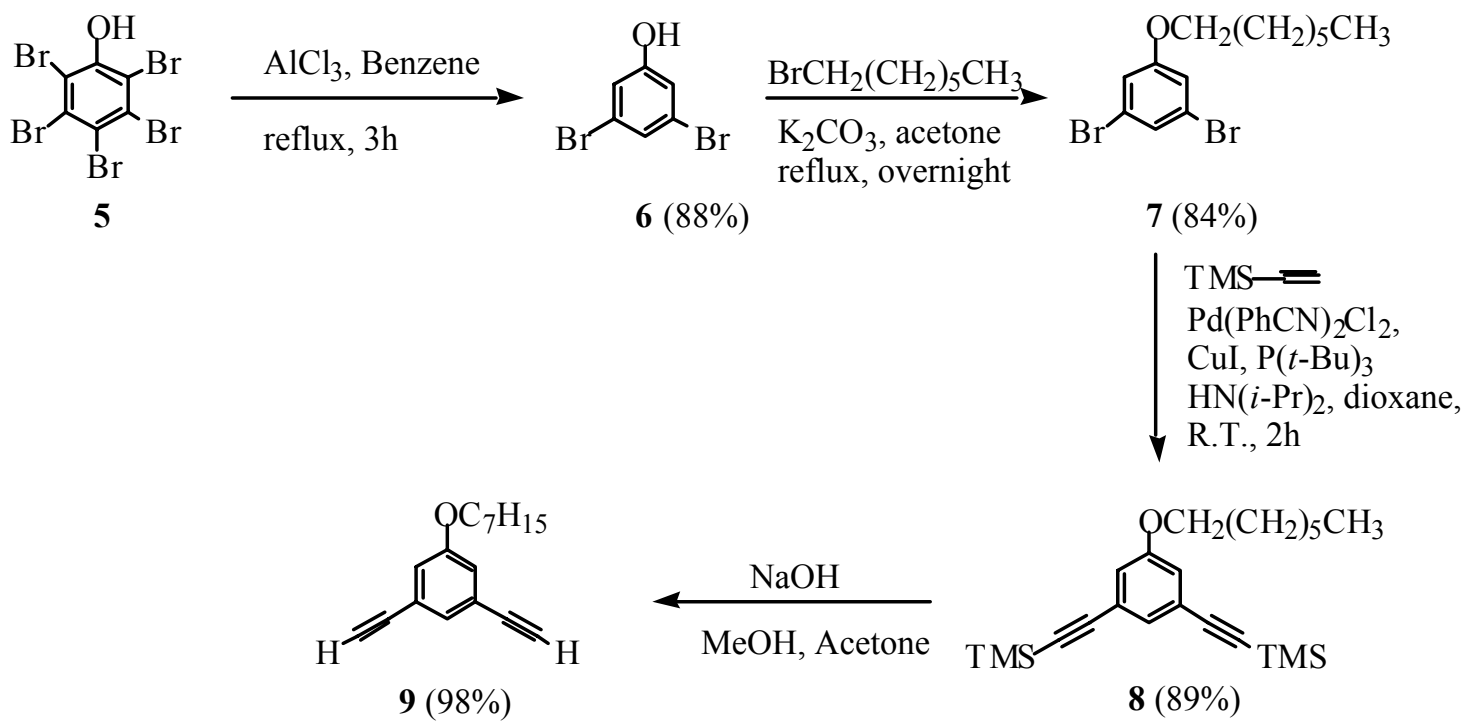

Of course, protection of one of the acetylenic groups of 9 could be a viable route for the synthesis of 2 via the Sonogashira reaction, however protection would introduce two more steps and would most certainly compromise the overall yield. Interestingly, both the first step of a possible protection route for the synthesis of 2, and the first step of the Suzuki/Miyaura route (Scheme 3) involve quantitative formation of the monoacetylide 10 by using a stoichiometric amount of a strong base. In the Suzuki/Miyaura route, 10 is activated with B-methoxy-9-BBN to form a stable methoxy(alkynyl)borate complex 11, which is then added to a solution of 3,8-dibromo-1,10-phenanthroline and a catalytic amount of $\mathrm{Pd}\left(\mathrm{PPh}_{3}\right)_{2} \mathrm{Cl}_{2}$ in THF. Intermediate 11 reacts in analogy to the alkynyl copper complex of the Sonogashira route yielding 2 in very good yield $(74 \%)$. 


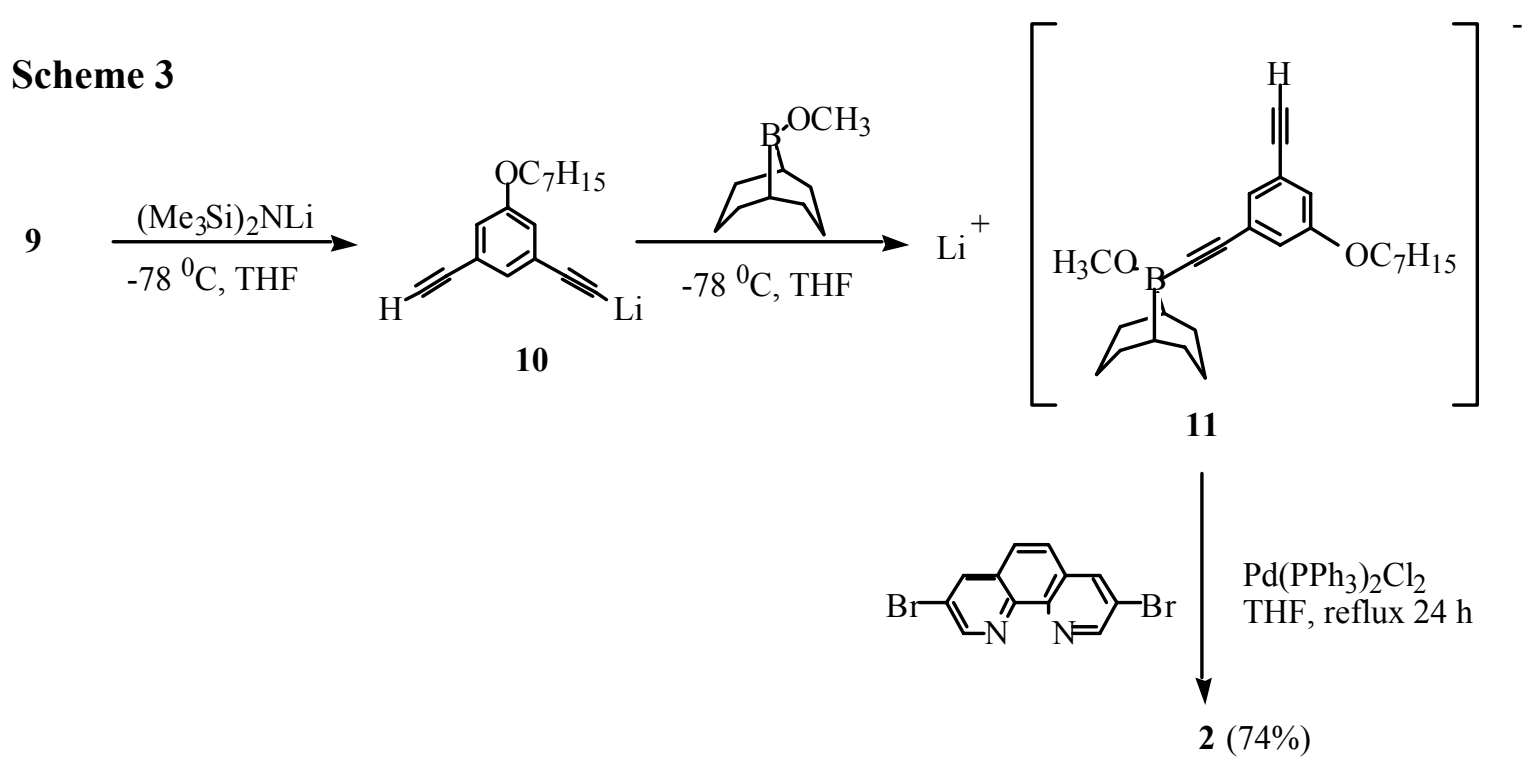

In conclusion, we have shown that coupling via the Suzuki/Miyaura route of two bifunctional reagents, namely 3,8-dibromophenanthroline and 3,5-diethynylheptyloxybenzene (9) gives compound 2 efficiently without polymerization.

\section{Experimental}

General. ${ }^{1} \mathrm{H}$ and ${ }^{13} \mathrm{C}$ NMR spectra were recorded on a Varian INOVA 400 NMR spectrometer and are reported as parts per million (ppm) from TMS $(\delta)$. Melting points were uncorrected. The Electrospray Mass Spectrometry (ESI) was conducted using a TSQ7000 (ThermoFinnigan) with an API2 source and the "performance pack" (wider aperture on the skimmer and extra turbo pump on the source). The electrospray source is equipped with a stainless steel needle; the voltage was $4.5 \mathrm{kV}$. Sample solutions were injected using a $500 \mathrm{uL}$ Gastight syringe (Hamilton) in a Pump 11 syringe pump (Harvard Apparatus).

Materials. All starting materials, reagents and solvents were from Aldrich or Acros and used as received, unless noted otherwise. $\mathrm{P}(\mathrm{t}-\mathrm{Bu})_{3}$ was purchased from Strem Chemicals. For coupling reactions, all the solvents were anhydrous and were obtained directly from Aldrich or Acros.

3,8-Bis(4-isonicotinoylphenylethynyl)-1,10-phenanthroline (1). 4-bromobenzoylpyridine ${ }^{7}$ (3, $0.68 \mathrm{~g}, 2.6 \mathrm{mmol}$ ), 3,8-diethynyl-1,10-phenanthroline ${ }^{8}$ (4, $\left.0.2 \mathrm{~g}, 0.88 \mathrm{mmol}\right), \mathrm{Pd}\left(\mathrm{PPh}_{3}\right)_{2} \mathrm{Cl}_{2}$ $(60 \mathrm{mg}, 0.085 \mathrm{mmol})$ and $\mathrm{CuI}(64 \mathrm{mg}, 0.34 \mathrm{mmol})$ were added to anhydrous diisopropylamine $(8 \mathrm{ml})$ and anhydrous DMF $(40 \mathrm{ml})$ under nitrogen and the reaction mixture was refluxed for $24 \mathrm{~h}$. After evaporation of the solvent under vacuum, the residue was diluted with $\mathrm{CH}_{2} \mathrm{Cl}_{2}$, washed with $5 \%$ aqueous $\mathrm{KCN}$ solution $(3 \times 20 \mathrm{ml})$, water $(5 \times 100 \mathrm{ml})$, and saturated aq. $\mathrm{NaCl}(100 \mathrm{ml})$. The organic phase was dried over anhydrous sodium sulfate, concentrated in vacuo followed by the addition of diethyl ether. The solid thus obtained was recrystallized from $\mathrm{CH}_{2} \mathrm{Cl}_{2} / \mathrm{THF}$ to give the product (0.17 g, 32\%). M.p. $266{ }^{\circ} \mathrm{C}$ (dec.); ${ }^{1} \mathrm{H}$ NMR $\left(400 \mathrm{MHz}, \mathrm{CDCl}_{3}\right) 9.32(\mathrm{~d}, J=1.83 \mathrm{~Hz}, 2 \mathrm{H})$, $8.85(\mathrm{~d}, J=5.68 \mathrm{~Hz}, 4 \mathrm{H}), 8.45$ (d, $J=1.83 \mathrm{~Hz}, 2 \mathrm{H}), 7.89$ (s, 2H), 7.86 (d, $J=5.49 \mathrm{~Hz}, 4 \mathrm{H}), 7.76$ 
$(\mathrm{d}, J=8.06 \mathrm{~Hz}, 4 \mathrm{H}), 7.60(\mathrm{~d}, J=5.68 \mathrm{~Hz}, 4 \mathrm{H})$; MS $(\mathrm{ESI}+) 591.1816(\mathrm{M}+\mathrm{H})^{+}$, (theoretical ionic mass: 590.1743).

3,5-dibromophenol (6). ${ }^{6}$ Aluminum chloride $(2.67 \mathrm{~g}, 0.02 \mathrm{~mol})$ was added to a solution of pentabromophenol $(5,5.0 \mathrm{~g}, 0.01 \mathrm{~mol})$ in anhydrous benzene $(20 \mathrm{ml})$ and the reaction mixture was heated to reflux for $3 \mathrm{~h}$ under nitrogen. After cooling to room temperature, the reaction mixture was poured into a mixture of $\mathrm{HCl}$ and ice water. The organic layer was separated and the water layer was extracted with diethyl ether $(3 \times 20 \mathrm{ml})$. The combined organic layers were extracted with $10 \%$ aqueous $\mathrm{NaOH}(3 \times 20 \mathrm{ml})$. The combined aqueous layers were made strongly acidic with $\mathrm{HCl}$. The product was then extracted with methylene chloride $(3 \times 20 \mathrm{ml})$ and the combined organic layers were washed with water until the aq. layer was neutral and then dried over anhydrous $\mathrm{Na}_{2} \mathrm{SO}_{4}$. Evaporation of the solvent in vacuo, gave the crude product which was recrystallized from hexane to give off-white needles $(2.3 \mathrm{~g}$, yield: $88 \%)$. Mp 81-82 ${ }^{\circ} \mathrm{C}$ (lit. ${ }^{6 \mathrm{a}} \mathrm{mp} 80{ }^{\circ} \mathrm{C}$, lit $\left.^{6 \mathrm{~b}}{ }^{\mathrm{m}} \mathrm{mp} 76-79{ }^{\circ} \mathrm{C}\right) ;{ }^{1} \mathrm{H}$ NMR $\left(400 \mathrm{MHz}, \mathrm{CDCl}_{3}\right) 4.85(\mathrm{~s}, 1 \mathrm{H}), 6.95(\mathrm{~d}, J=1.65$ $\mathrm{Hz}, 2 \mathrm{H}), 7.25(\mathrm{t}, J=1.65 \mathrm{~Hz}, 1 \mathrm{H}) ;{ }^{13} \mathrm{C} \mathrm{NMR}\left(100 \mathrm{MHz}, \mathrm{CDCl}_{3}\right) 156.4,126.8,123.1,117.8$.

3,5-dibromoheptyloxylbenzene (7). A mixture of 3,5-dibromophenol (6, $5.0 \mathrm{~g}, 0.02 \mathrm{~mol})$, potassium carbonate $(2.76 \mathrm{~g}, 0.02 \mathrm{~mol})$, and 1-bromoheptane $(3.1 \mathrm{ml}, 0.02 \mathrm{~mol})$ in acetone $(50 \mathrm{ml})$ was stirred at reflux overnight. After cooling to room temperature, water $(50 \mathrm{ml})$ was added and the reaction mixture was extracted with diethyl ether $(3 \times 20 \mathrm{ml})$. The combined organic layers were washed first with aqueous $10 \% \mathrm{NaOH}$, followed by water, dried over anhydrous $\mathrm{Na}_{2} \mathrm{SO}_{4}$ and evaporated to dryness under vacuum. The oil thus obtained was distilled under vacuum to give a colorless liquid (5.4 g, 84\%); bp $145{ }^{\circ} \mathrm{C} / 0.5$ torr; ${ }^{1} \mathrm{H}$ NMR $\left(400 \mathrm{MHz}, \mathrm{CDCl}_{3}\right) 0.89$ $(\mathrm{t}, J=6.96 \mathrm{~Hz}, 3 \mathrm{H}), 1.29-1.46(\mathrm{~m}, 8 \mathrm{H}), 1.72-1.79(\mathrm{~m}, 2 \mathrm{H}), 3.90(\mathrm{t}, J=6.50 \mathrm{~Hz}, 2 \mathrm{H}), 6.97$ $(\mathrm{d}, J=1.65 \mathrm{~Hz}, 2 \mathrm{H}), 7.22(\mathrm{t}, J=1.65 \mathrm{~Hz}, 1 \mathrm{H}) ;{ }^{13} \mathrm{C} \mathrm{NMR}\left(100 \mathrm{MHz}, \mathrm{CDCl}_{3}\right)$ 160.6, 126.3, 123.3, $117.1,68.8,32.1,29.3,26.2,22.9,14.4$.

3,5-bis(trimethylsilylethynyl)heptyloxylbenzene (8). $\mathrm{Pd}\left(\mathrm{PhCN}_{2} \mathrm{Cl}_{2}(46 \mathrm{mg}, 0.12 \mathrm{mmol})\right.$ and $\mathrm{CuI}(15.2 \mathrm{mg}, 0.08 \mathrm{mmol})$ were added to a dry, septum-capped round bottom flask, purged with nitrogen. Anhydrous dioxane $(2 \mathrm{ml}), \mathrm{P}(\mathrm{t}-\mathrm{Bu})_{3}\left(0.5 \mathrm{ml}, 0.25 \mathrm{M}\right.$ solution in dioxane), $\mathrm{HN}(\mathrm{i}-\mathrm{Pr})_{2}$ $(0.68 \mathrm{ml}, 4.8 \mathrm{mmol}), 7(0.7 \mathrm{~g}, 2 \mathrm{mmol})$ in $0.5 \mathrm{ml}$ dioxane were then added via syringe to the stirred reaction mixture. Finally, trimethylsilylacetylene $(0.66 \mathrm{ml}, 4.6 \mathrm{mmol})$ was added to the flask. In a few minutes, a precipitate was formed. After stirring the reaction mixture at room temperature for $2 \mathrm{~h}$, the solvent was evaporated to dryness and the crude product was purified on a silica gel column using $2 \% \mathrm{CH}_{2} \mathrm{Cl}_{2}$ in hexane as eluent. The product was further purified by recrystallization from methanol to give a yellow solid $(0.68 \mathrm{~g}$, yield $89 \%)$. Mp $47{ }^{\circ} \mathrm{C} ;{ }^{1} \mathrm{H} \mathrm{NMR}\left(400 \mathrm{MHz}, \mathrm{CDCl}_{3}\right)$ $7.16(\mathrm{t}, J=1.47 \mathrm{~Hz}, 1 \mathrm{H}), 6.94(\mathrm{~d}, J=1.28 \mathrm{~Hz}, 2 \mathrm{H}), 3.91(\mathrm{t}, J=6.50 \mathrm{~Hz}, 2 \mathrm{H}), 1.71-1.79(\mathrm{~m}, 2 \mathrm{H})$, $1.28-1.46(\mathrm{~m}, 8 \mathrm{H}), 0.89(\mathrm{t}, J=5.78 \mathrm{~Hz}, 3 \mathrm{H}), 0.22(\mathrm{~s}, 18 \mathrm{H})$.

3,5-Bis(ethynyl)heptyloxylbenzene (9). 8 (3.35 g, $8.7 \mathrm{mmol})$, acetone $(30 \mathrm{ml})$, methanol $(60 \mathrm{ml})$, and $\mathrm{NaOH}(0.12 \mathrm{~g}, 3 \mathrm{mmol})$ were mixed together and stir at room temperature for $2 \mathrm{~h}$. Water $(100 \mathrm{ml})$ was then added, followed by extraction with diethyl ether $(3 \times 50 \mathrm{ml})$. The combined ether extracts were washed with water until the aqueous layer was neutral, dried with anhydrous $\mathrm{Na}_{2} \mathrm{SO}_{4}$ and evaporated to dryness in vacuo to give a yellow solid $(2.05 \mathrm{~g}, 98 \%)$. $\mathrm{Mp} 32{ }^{\circ} \mathrm{C} ;{ }^{1} \mathrm{H}$ NMR $\left(400 \mathrm{MHz}, \mathrm{CDCl}_{3}\right) 7.20$ (t, $\left.J=1.28 \mathrm{~Hz}, 1 \mathrm{H}\right), 6.99(\mathrm{~d}, J=1.28 \mathrm{~Hz}, 2 \mathrm{H}), 3.93$ | $(\mathrm{t}, J=6.59 \mathrm{~Hz}, 2 \mathrm{H}), 3.05(\mathrm{~s}, 2 \mathrm{H}), 1.72-1.80(\mathrm{~m}, 2 \mathrm{H}), 1.28-1.46(\mathrm{~m}, 8 \mathrm{H}), 0.89(\mathrm{t}, J=6.95 \mathrm{~Hz}, 3 \mathrm{H})$;

${ }^{13} \mathrm{C}$ NMR (100 MHz, $\left.\mathrm{CDCl}_{3}\right)$ 158.6, 128.0, 123.2, 118.8, 82.6, 77.5, 68.2, 31.7, 29.1, 29.0, 25.9, 22.6, 14.1; MS (ESI+) 241.1587 $(\mathrm{M}+\mathrm{H}){ }^{+}{ }^{+}$(theoretical ionic mass: 240.1514).

3,8-bis(3-ethynyl-5-heptyloxyphenylethynyl)-1,10-phenanthroline

(2). Lithium bis(trimethylsilyl)amide ( $2.25 \mathrm{mmol}, 2.25 \mathrm{ml}$ of $1 \mathrm{M}$ solution in THF) was added under nitrogen to 
a well stirred solution of $9(0.86 \mathrm{~g}, 2.25 \mathrm{mmol})$ in anhydrous THF $(10 \mathrm{ml})$ at $-78{ }^{\circ} \mathrm{C}$. After $30 \mathrm{~min}$, B-methoxy-9-BBN (2.25 mmol, $2.25 \mathrm{ml}$ of $1 \mathrm{M}$ solution in hexane) was added to the reaction mixture via a septum with a syringe. After stirring for $2 \mathrm{~h}$ at $-78{ }^{\circ} \mathrm{C}$, the solution was transferred via a cannula to a second flask containing $\mathrm{Pd}\left(\mathrm{PPh}_{3}\right)_{4}(60 \mathrm{mg}, 0.052 \mathrm{mmol})$ and 3,8-dibromo-1,10-phenanthroline $(0.25 \mathrm{~g}, 0.75 \mathrm{mmol})$ in dry THF $(30 \mathrm{ml})$ under nitrogen. The reaction mixture was then heated to reflux for $24 \mathrm{~h}$ and cooled to room temperature. Methylene chloride $(50 \mathrm{ml})$ was added and the organic layer was washed with water $(20 \times 100 \mathrm{ml})$ dried with anhydrous $\mathrm{Na}_{2} \mathrm{SO}_{4}$ and evaporated to dryness. The crude product thus obtained was purified on silica gel column. Initial elution with $\mathrm{CH}_{2} \mathrm{Cl}_{2}$ gave unreacted starting material. Subsequent elution with diethyl ether gave the product. After removal of the solvent in vacuo a light yellow solid was obtained (0.36 g, $74 \%)$. Mp 85-86 ${ }^{\circ} \mathrm{C} ;{ }^{1} \mathrm{H} \mathrm{NMR}\left(400 \mathrm{MHz}, \mathrm{CDCl}_{3}\right) 9.25(\mathrm{~d}, J=2.01 \mathrm{~Hz}, 2 \mathrm{H}), 8.34$ $(\mathrm{d}, J=2.01 \mathrm{~Hz}, 2 \mathrm{H}), 7.78(\mathrm{~s}, 2 \mathrm{H}), 7.33(\mathrm{t}, J=1.28 \mathrm{~Hz}, 2 \mathrm{H}), 7.12(\mathrm{t}, J=1.46 \mathrm{~Hz}, 2 \mathrm{H}), 7.05$ $(\mathrm{t}, J=1.28 \mathrm{~Hz}, 2 \mathrm{H}), 3.98(\mathrm{t}, J=6.5 \mathrm{~Hz}, 4 \mathrm{H}), 3.10(\mathrm{~s}, 2 \mathrm{H}), 1.78-1.82(\mathrm{~m}, 4 \mathrm{H}), 1.48(\mathrm{~m}, 8 \mathrm{H})$, $1.28-1.46(\mathrm{~m}, 8 \mathrm{H}), 0.91(\mathrm{t}, J=6.87 \mathrm{~Hz}, 6 \mathrm{H}) ;{ }^{13} \mathrm{C} \mathrm{NMR}\left(100 \mathrm{MHz}, \mathrm{CDCl}_{3}\right)$ 158.6, 152.1, 144.2, $137.9,127.8,127.5,126.7,123.4,123.3,119.2,118.9,118.0,92.9,86.4,82.5,77.6,68.2,31.7$, 29.0, 28.9, 25.8, 22.5, 14.0; MS (ESI+) $657.3476(\mathrm{M}+\mathrm{H}){ }^{+}{ }^{+}$(theoretical ionic mass: 656.3403).

\section{References}

1. (a) Sonogashira, K.; Tohda, Y.; Hagihara, N. Tetrahedron Lett. 1975, (50), 4467-4470. (b) Cassar, L. J. Organomet. Chem. 1975, 93, 253-257. (c) Dieck, H. A.; Heck, R. F. J. Organomet. Chem. 1975, 93, 259-263. (d) Hundertmark T.; Littke A. F.; Buchwald S. L.; Fu G. C., Org. Lett. 2000, 2(12), 1729-1731. (e) Thorand, S.; Krause, N. J. Org. Chem. 1998, 63, 8551-8553. (f) Nakamura, K.; Okubo, H.; Yamaguchi, M. Synlett 1999, 5, 549-550. (g) Bohm, V. P. W.; Herrmann, W. A., Eur. J. Org. Chem. 2000, 3679-3681. (h) Pearson, D. L.; Schuman, J. S.; Tour, J. M. Macromolecules 1994, 27, 2348-2350.

2. (a) Rossi, R.; Carpita, A.; Bigelli, C. Tetrahedron Lett. 1985, 26(4), 523-526. (b) Ikegashira, K.; Nishihara, Y.; Hirabayashi, K.; Mori, A.; Hiyama, T. Chem. Commun. 1997, 1039-1040. (c) Nishihara, Y.; Ikegashira, K.; Hirabayashi, K.; Ando, J.; Mori, A.; Hiyama, T. J. Org. Chem. 2000, 65, 1780-1787. (d) Hay, A. S. J. Org. Chem. 1960, 25, 1275-1276. (e) Hay, A. S. J. Org. Chem. 1962, 27, 3320-3321.

3. (a) Soderquist, J. A.; Matos, K.; Rane, A.; Ramos, J. Tetrahedron Lett. 1995, 36(14), 2401-2402. (b) Soderquist, J. A.; Rane, A. M.; Matos, K.; Ramos, J. Tetrahedron Lett. 1995, 36(38), 6847-6850. (c) Castanet, A. S.; Colobert, F.; Schlama, T. Org. Lett. 2000, 2(23), 3559-3561.

4. According to the literature, direct Sonogashira couplings on 3,8-dibromo-1,10-phenanthroline are complicated by complexation of the $\mathrm{Cu}(\mathrm{I})$ catalyst with the phenanthroline's nitrogens. ${ }^{5 \mathrm{a}}$ In that respect, Sonogashira coupling of Ru(II)-coordinated 3,8-dibromo-1,10-phenanthroline works exceptionally well. ${ }^{5 \mathrm{~b}}$

5. (a) Suffert, J.; Ziessel, R. Tetrahedron Lett. 1991, 32, 757-760. (b) Tzalis, D.; Tor, Y. Chem. Commun. 1996, 1043-1044.

6. (a) Ishida, Y.; Jikei, M.; Kanimoto, M. Polym. Adv. Technol. 2000, 11, 698-704. (b) Kraus, R.; Spiteller, G. Organic Mass Spectrometry 1989, 24, 861-865.

7. Leventis, N.; Elder, I. A.; Gao, X.; Bohannan, E. W.; Sotiriou-Leventis, C.; Rawashdeh, A.-M. M.; Overschmidt, T. J.; Gaston, K. R. J. Phys. Chem. B 2001, 105, 3663-3674.

8. Joshi, H. S.; Jamshidi, R.; Tor, Y. Angew. Chem. Int. Ed. 1999, 38(18), 2722-2725. 
Public reporting burden for this collection of information is estimated to average 1 hour per response, including the time for reviewing instructions, searching existing data sources, gathering and maintaining the data needed, and completing and reviewing the collection of information. Send comments regarding this burden estimate or any other aspect of this collection of information, including suggestions for reducing this burden, to Washington Headquarters Services, Directorate for Information Operations and Reports, 1215 Jefferson Davis Highway, Suite 1204, Arlington, VA 22202-4302, and to the Office of Management and Budget, Paperwork Reduction Project (0704-0188), Washington, DC 20503.

\begin{tabular}{|l|c|c|}
\hline 1. AGENCY USE ONLY (Leave blank) & $\begin{array}{r}\text { 2. REPORT DATE } \\
\text { September } 2003\end{array}$ & $\begin{array}{r}\text { 3. REPORT TYPE AND DATES COVERED } \\
\text { Technical Memorandum }\end{array}$ \\
\hline 4. TITLE AND SUBTITLE & 5. FUNDING NUMBERS
\end{tabular}

Coupling of 3,8-Dibromo-1,10-Phenanthroline With 3,5-Diethynylheptyloxybenzene: A Suzuki/Miyaura Versus a Sonogashira Perspective

WBS-22-708-93-05

\section{AUTHOR(S)}

Jinhua Yang, Woon Su Oh, Ian A. Elder, Nicholas Leventis, and Chariklia Sotiriou-Leventis

\section{PERFORMING ORGANIZATION NAME(S) AND ADDRESS(ES)}

National Aeronautics and Space Administration

John H. Glenn Research Center at Lewis Field

Cleveland, Ohio 44135-3191

8. PERFORMING ORGANIZATION REPORT NUMBER

E-14027

\section{SPONSORING/MONITORING AGENCY NAME(S) AND ADDRESS(ES)}

National Aeronautics and Space Administration

Washington, DC 20546-0001

10. SPONSORING/MONITORING AGENCY REPORT NUMBER

NASA TM-2003-212485

\section{SUPPLEMENTARY NOTES}

This work was submitted to the Synthetic Communications journal. It was accepted for publication with no revision. It will appear in print with the following bibliographic entry: Synthetic Communications, Vol. 33, No. 19, pp. 3317-3325, 2003. Jinhua Yang, Woon Su Oh, Ian A. Elder, and Chariklia Sotiriou-Leventis, University of Missouri at Rolla, Rolla, Missouri 65409; Nicholas Leventis, NASA Glenn Research Center. Responsible person, Nicholas Leventis, organization code 5150, 216-433-3202.

12a. DISTRIBUTION/AVAILABILITY STATEMENT 12b. DISTRIBUTION CODE

Unclassified - Unlimited

Subject Category: 23

Distribution: Nonstandard

Available electronically at http://gltrs.grc.nasa.gov

This publication is available from the NASA Center for AeroSpace Information, 301-621-0390.

13. ABSTRACT (Maximum 200 words)

We report a new application of the Suzuki-Miyaura reaction whereas two bifunctional reactants, 3,8-dibromo-1,10phenanthroline and 3,5-diethynylheptyloxylbenzene (9), yield 3,8-bis(3-ethynyl-5-heptyloxyphenylethynyl)-1,10phenanthroline (2) efficiently (74 percent yield) without polymerization. This was achieved by reacting a stoichiometric amount of 9 and $\left(\mathrm{Me}_{3} \mathrm{Si}\right)_{2} \mathrm{NLi}$ to obtain quantitatively the monoacetylide anion of $\mathbf{9}(\mathbf{1 0})$. The latter was activated with B-methoxy-9-BBN and reacted in analogy to the alkynyl copper complex of a Sonogashira route. However, in the Sonogashira reaction, the alkynyl copper complex is present in small equilibrium concentrations and polymerization takes place even when reagents are mixed slowly. Actually the Sonogashira route gave no desired product $\mathbf{2}$, as the latter polymerizes easily via homo-coupling in the presence of air and $\mathrm{Cu}(\mathrm{I})$.

14. SUBJECT TERMS

Suzuki/Miyaura coupling; Sonogashira coupling

17. SECURITY CLASSIFICATION OF REPORT

Unclassified

\section{SECURITY CLASSIFICATION OF THIS PAGE \\ Unclassified}

19. SECURITY CLASSIFICATION OF ABSTRACT

Unclassified
15. NUMBER OF PAGES

12

16. PRICE CODE

20. LIMITATION OF ABSTRACT

Standard Form 298 (Rev. 2-89)

Prescribed by ANSI Std. Z39-18 298-102 